\title{
Technological innovation policy in China: the lessons, and the necessary changes ahead
}

\author{
Xiaolan Fu \\ Wing Thye Woo \\ Jun Hou \\ Key words \\ Technology Innovation Openness Policy China
}

\begin{abstract}
China has now moved considerably away from being an imitative latecomer to technology toward to being an innovation-driven economy. The key lessons from China's experience are that (1) there is synergy between External Knowledge and Indigenous Innovation because the process of learning the tacit knowledge required in using the foreign technology fully is made easier by strong in-house R\&D capability; (2) the open innovation approach is very important because it allows multiple driving forces - the state, the private sector and MNEs - with each playing a changing role over time; and (3) the commencement of foreign technology transfer and investment in indigenous innovation should go hand in hand. Without the numerous well-funded programs to build up the innovation infrastructure to increase the absorptive capacity of Chinese firms, foreign technology would have remained static technology embedded in imported machines and would not have strengthened indigenous technological capability. However, China could still end up in the middle-income trap, unless it undertakes a series of critical reforms in its innovation regime in order to keep moving up growth trajectories that are increasingly skill-intensive and technology-intensive.
\end{abstract}




\section{Technological innovation and economic development}

Kuznets (1966) coined the term "modern economic growth" to characterize the growth experiences in Western Europe, North America, and Japan in the last 300 years. Their growth was "modern" because there was a permanent increase in the trend growth rate of labor productivity; there were large permanent shifts in the composition of output and employment away from agriculture towards industries and services; and there was systematic application of science to improve production techniques. Marx and Engels (1848) were among the earliest social scientists to bring attention forcefully to this historic transition in the economic system. Marx and Engels saw the inherent conflict between "the oppressor and the oppressed" as leading to the introduction of new production techniques to enable the replacement of labor in production, and hence weaken its bargaining power. In Marx and Engel's analysis, this steady flow of new technologies had transformed the economic base structure that had, in turn, created a new socio-political superstructure.

However, some social scientists like North and Thomas (1973) have reversed the direction of causality to argue that it was innovations in the socio-political institutions (e.g. the re-arrangement of the political and property rights system) that had unleashed technological progress to become a near-continual phenomenon. Still yet other schools of thought would identify different factors for the variegated pattern of industrialization experiences globally. For example, Weber (1905) and Landes (1998) have attributed this variegated global pattern to differences in cultural attitudes; and Kamarck (1976) and Diamond (1997) have postulated the pattern to be the product of geographical factors like disease burden and conditions for agriculture.

However, despite great disagreement on what is (are) the ultimate causal factor (factors) of growth, most of these competing schools would agree with the central feature of the Solow (1970) model that a high rate of technological innovation is, at the minimum, the proximate cause of a high trend growth rate of productivity. A high rate of productivity growth could not endure without a persistently high rate of innovation.

We have two objectives in this paper. The first is to examine China's post-1978 experience with technological innovations to identify economic policies that other developing countries could implement in order to improve their performance in innovation. 1 The second objective is to suggest how China should reform its innovation system to sustain the transition to a knowledge-based economy.

A key difference between a developing country and a developed country is that most of the firms in the developing country are not using advanced production technology, while many of the firms in the developed countries are. Hence, productivity growth in a developing country could be increased in two ways: by adopting more advanced existing technology from abroad, and by strengthening indigenous technological innovations. This paper will analyse how China has used these two channels of innovation since 1978, and how China's innovation policy has evolved over time.

The paper is organized as follows. Section 2 discusses China's efforts to acquire technological knowledge from abroad. Section 3 identifies China's key policies to improve indigenous innovation capability. Section 4 highlights China's programs to enlarge its' talent pool. Section 5integrates the findings in the proceeding sections to give an analytical framework to see the coherence in China's policies to accelerate the pace of innovation. Section 6 discusses what China must do next in its innovation strategy in order to ensure that China would reach the global frontier of technology and be a contributor to world technological progress. 


\section{The acquisition of foreign technological knowledge}

In the context of developing countries like China, innovation concerns not only novel innovations but also innovation via diffusion of existing ideas and techniques. Cooper (1989) has pointed out that most firms in developing countries attempt to reach the technological frontier instead of achieving inventions that are new to the market. In-house innovative activities are severely constrained in the majority of developing countries because of inadequate capital and infrastructure. Foreign technology sources have therefore been the primary driver of innovation in many developing countries, especially at the beginning of their industrialization.

Foreign technology can be transferred between firms and across regions and countries through various transmission mechanisms. These include (1) licensing; (2) movement of goods through international trade, especially imports; (3) movement of capital through inward and outward foreign direct investment (FDI and OFDI); (4) movement of people through migration, travel, and foreign education of students and workers; (5) international research collaboration; (6) diffusion through media and the Internet of disembodied knowledge; and (7) integration into global value chains to benefit from the foreign technology transferred within the supply chain. Some knowledge is transferred intentionally from the knowledge owner to the recipient-and this may spur a learning process - but a large proportion of knowledge spill-overs take place as unintended knowledge leakage.

China's innovation path was no exception. China has gone through a dynamic process in which foreign sources of knowledge has played a critical role in particular at the initial stage, and in which the channels used for foreign technology transfer also evolved with the rapid development of China's technological base. In the 1950s, the major source of technology for China was the former Soviet Union. After the withdrawal of all Soviet advisers from China in 1960 and the rupture of Chinese-Soviet relations in 1962, western countries and Japan became the main technology suppliers in heavy industry.

When the economic open-door policy was launched in 1976 to support the Four Modernisation campaign, technology transfer became diversified through the purchase of turnkey plants and equipment, and in the form of disembodied technology including licensing, technical consulting, technical service and co-production. Direct adoption of these technologies and learning how to use the imported machines were the main efforts made by domestic firms and institutions in 1980s. In 1985 , the central government initiated the science and technology system reform which defined the acquisition of foreign technology as one of the main technological sourcing strategy for promoting technology development. Technology transfer through direct foreign investment became a new focus, and, with help mainly from subsidiaries of MNEs, the capabilities of the high-technology industries increased considerably. Five countries - the US, Japan, Germany, France and the UKdominated the supply of technology to China at that time.

After 1995, policies were designed to speed up the advancement of indigenous science and technology. These included introducing incentives to firms to set up R\&D units. This resulted in radical increase of these units, from 7000 in 1987 to 24,000 by 1998, and then to 46,000 in 2012 (China Science and Technology Statistics 1992, 1998, 2013).2

In 2006, China declared indigenous innovation to be a strategic priority, and China, and started shifting its innovation focus from external acquisition of knowledge to internal creation of knowledge. This policy shift is well captured in Fig. 1. The expenditure on imported technology has 
declined from $0.088 \%$ of GDP in 2006 to $0.076 \%$ of GDP in 2013. The total expenditure on importing foreign technology has two components (1) expenditure on direct technology purchases and (2) expenditure on imported equipment. Figure 1 shows a clear decrease in importing equipment since 2006 , which is a strong signal of the desire to have the major technology sources be domestic suppliers and not foreign suppliers.

Simultaneously, China diversified its networks to obtain foreign technological knowledge. China is funding more Chinese participation in international innovation collaboration (foreign contracted projects), and encouraging Chinese firms to go abroad to invest in and acquire foreign technology companies. Figure 2 shows that, in 2013, outward FDI and foreign contracted projects have reached USD 107.8 billion and USD 171.6 billion respectively while inward FDI was USD 118.7 billion.

By the end of 2010, China had established formal S\&T relations with 152 countries and regions and signed 104 cooperation agreements (China Statistic Yearbook 2011). An ever-intensifying web of international connections has spread across every aspect of China's innovation system. We think that that international innovation collaboration and outward FDI have a greater likelihood of creating radical novel innovations in the Chinese firms than inward FDI because Fu (2008) has found that the benefits to the technological and innovation capabilities of Chinese firms from inward FDI are limited, despite some learning by the indigenous partner in the joint ventures and spill-overs to local companies in the same and linked industries.

\section{Improving the infrastructure for indigenous innovation}

China's Science \&Technology (S\&T) infrastructure has experienced a significant growth in the last three decades. Among the key, large-scale S\&T programs initiated by the state in 1980-2000 period were:

- the 'Key Technologies R\&D Program' in 1982 that aims at making breakthroughs in technologies. The focus this program is set on a four-year cycle so that it could evolve in line with the changing needs of the economy;

- the 'Spark Program' in 1986 that promoted technological upgrading by small and medium enterprises (SMEs) in the rural communities;

- the 'High-Tech Research and Development Program' (also known as 863 program) in 1987 that expanded the dissemination advanced technological insights in order to reduce the technological knowledge gap between China and the developed world;

- the 'Torch program' in 1988 to serve as the backbone of high-tech industrial revolution in China by providing the legal and organizational frameworks for the creation and growth of high-tech industrial development zones;

- the Innovation Fund for Technology-based small and medium-scaled Enterprises in 1993 to award grants to start-up technological companies;

- the campaign to "revitalize the nation through science and education" (Ke Jiao Xing Guo) in 1995; and

- the 'National Key Basic Research Program' (also known as the 973 Program) in 1997 to restructure the different overlaying programs and increased financing to basic research. 
As an outcome of these initiatives, R\&D expenditure in China rose RMB 34.9 billion in 1995 to RMB 10,298 billion in 2012, i.e. an increase of almost 30 -fold. R\&D spending increased at an average annual real growth rate of almost $20 \%$ and this has made China the third largest global investor in R\&D, just behind the United States and Japan, but ahead of individual economies of the EU. Figure 3 reports the huge increase in investment in R\&D from 1995 to 2012.3 The R\&D intensity of China's economy, measured as R\&D expenditure as a percentage of gross domestic products (GDP), has soared steadily from $0.57 \%$ of GDP in 1995 to $1.32 \%$ in 2005 and then to $1.98 \%$ in 2012.

Frequently, the generous infusion of research funds to public universities and other state scientific institutions (e.g. state experimental laboratories) was accompanied by the directive that they devise effective ways to diffuse the advanced knowledge into the economy. One way for these research institutions to do so is to set up technology companies, often as independent incorporated entities.

Many of these spin-off technology companies were very successful, and this encouraged the government to begin incorporating large public R\&D institutions as units within large business enterprises. For example, Lenovo took over the running of the Institute of Computing Technology of the CAS in 1995, approximately 10 years after Lenovo was spun out from that Institute.

The transformation of applied research institutes into business entities has translated into a growing share of R\&D funded and performed by business enterprises. This share has risen from about $50 \%$ in the late 1990s to more than $70 \%$ in 2011 (China S\&T Statistics Year Book, various years).

Figure 4 documents that business enterprises and government have accounted for over $90 \%$ of R\&D spending in China since 2004, with enterprises responsible for 74 \%age points in 2011. Foreignfunded R\&D in China has been very limited.

The significant expansion of China's technology base can also be seen by the rapid increase in the number of R\&D personnel. R\&D personnel includes all persons employed directly on research and development activities, as well as those providing direct services such as R\&D managers, administrators and clerical staffs (OECD 2002). Since 2006, China has had the second highest number of researchers in the world, just behind the United States.

Figure 5 reports the steady fast increase in the number of R\&D personnel, calculated in full-time equivalents (FTE), since 1995. When the R\&D personnel is broken down by type of activities, it shows that the largest increase in the number of researchers is in response to the tremendous growth of experimental development activities. There rise in the number of researchers in basic research and in applied research is considerably much more modest.

\section{Enlarging and upgrading the talent pool}

A major problem in low-income nations is the 'brain drain' where the best and brightest university graduates leave the country to seek higher quality education and higher paying employment abroad. In the 1960-1985 period, the United States was the preferred destination for many educated nationals from South Korea and Taiwan, leading to a substantial brain drain for these economies. Large-scale outflow of college-educated Indians to the United States was recorded in the 1980-2000 period.

The outflow of students from China began in 1978 with the initiation of economic reform. Figure 6 documents that there was a significant increase in this movement in the first half of the 1990s, and that the outflow rose off dramatically in the 2000s. The number of foreign-educated Chinese who return from abroad increased each year but the rate of increase was low before 2006. 
The rate of increase in the number of foreign-educated returnees each year has increased since 2008. The change in the nature of Chinese brain drain is seen in that ratio of returnees to "departees" was $28 \%$ in 1995 and $31 \%$ in 2006, but rose to a stunning $79 \%$ in 2014.

China has benefited tremendously from the recent phenomenon of "reverse brain drain" just like the economies of South Korea and Taiwan did in the late 1980s. These returnees have played an important role in the development of some high-technology industries and the strategic emerging industries such as renewable energy, electrical cars and biotechnology (Wang 2012).

The high rate of returning students after 2008 is the result of pull-and-push factors. The single biggest push factor was the Global Financial Crisis in 2008 and the very slow recovery of the developed countries that followed. Another push factor for the Chinese graduates in the developed was the glass ceiling that made the highest-level jobs out of reach.

The pull factors increased in strength over time. The now more developed China and its continued high growth rate offered unprecedented job opportunities for high-skilled graduates and unprecedented growth possibilities for the entrepreneurially-inclined graduates. At the same time, the central government launched several talent programs to encourage Chinese researchers to return. For example, the '973 Program' started in 1997 and the 'Thousand Talents Program' guaranteed large research funding and high salaries.

The central government has not been alone in the international recruitment program. Local governments in their bid to support start-ups in high-technology parks competed extremely aggressively to attract returnees to their vicinities. Motivation packages include tax breaks for new firms, cheap or free land use, reduced cost of housing, and tax-free import of equipment. Returning entrepreneurs with foreign technology and financing to build substantial ventures could shop around various locations for the best deal (Li 2011).

A large number of companies set up by Chinese expatriates in the 2000s were concentrated in the ICT sectors because it was much easier to introduce new ventures into the well-defined global network of firms engaged in production of ICT items. Furthermore, the very existence of these global networks ensured that the global contacts and knowledge of the returnees were highly valued (Zhou 2008; Zhou and Hsu 2011).

The booming solar panel industry in China is good proof that the entrepreneurial activities of the returnees go well beyond the ICT industry. Chinese solar panel companies such as Suntech Power and Trina Solar, which were founded by returnee scientists and engineers, have become global leaders.

\section{An analytical framework for China's innovation policy}

This section will present an analytical framework to show the coherence in the innovation policies taken by China in Sects. 2, 3 and 4 by explaining how they created a virtuous circle in enlarging China's prowess in innovation.

We start with the recognition that there are two sources of innovation for a country: external acquisition and internal creation. It may appear that the choice between the two is a straightforward one: which investment would yield a higher rate of return? The difficulty in answering this question convincingly is that only the rate of return on the known foreign technology could be calculated with any confidence. In this selection between the known rate of return and the unknown rate of return, the developing country is likely to opt for external acquisition because they cannot afford the high 
cost and high risk associated with original innovation. This is also because knowledge is accumulative and path-dependent.

Other considerations would also support the conclusion that the chosen source of innovation depends on the stage of development. As a low-income developing country typically has a population with low education and near-negligible capability in technological innovation, the external acquisition of innovation is the only practical route available.4 On the other hand, when a country is fully developed and on the global frontier of technology, the source of innovation might then be indigenous innovation because it has the ability to engage in this endeavour.

There are four reasons why the above conclusion should be modified. The first is simply that there is neither logical nor technical need for the policy options to be cast in dichotomous terms because one could use both sources simultaneously. The relevant issue is the proportion of investment on each source of innovation, i.e. the optimum portfolio of investments for each country depends on its set of national circumstances.

The second reason is that there are middle-income countries besides low-income and high-income countries. Even if the "correct" answer is that external acquisition is best for low-income countries and indigenous innovation for high-income countries, it would seem that a combination of these sources is best for middle-income countries.

The third reason is based on the current conditions of the world economy. A country that embraces indigenous innovation as its sole source of innovation is embracing what Chesbrough (2003) has called Closed Innovation Principles. As the present state of the international economy is characterized by (1) a large number of highly talented researchers in many developed countries, (2) high job mobility across firms and developed countries, and (3) useful knowledge being widely distributed and of high quality, any advanced country that would use only technology that it invents itself would almost surely fall behind its competitors over time. This is why Chesbrough advocates open innovation (utilizing both sources of innovation) over closed innovation (relying only upon indigenous innovation). 5 Closed innovations-exclusive reliance on indigenous innovation alone-is just not a sustainable innovation policy regime in a competitive world.

The fourth and most important reason for drawing on both sources of innovation comes from the fact that the ease of mastering foreign technological knowledge increases with the capability of the country in indigenous innovation. The buying of foreign technology is one thing but then being able to use it fully is another. Technological learning is not a straightforward task even when one has prior technical training in the activity into which the new production technology is introduced. This is because there are two types of knowledge about the innovation that must be mastered before it could be used to its full potential (1) explicit, codified knowledge and (2) tacit knowledge.

Codified knowledge is knowledge that is articulated into formal language, including grammatical statements, mathematical expressions, specifications, manuals, and so on. This articulation means that explicit knowledge can be readily transmitted and shared with others. The speed with which codified knowledge is assimilated by the recipient is more a function of the recipient's intellectual capacity and less a matter of the time spent gaining experience of the subject matter.

Tacit knowledge is personal knowledge embedded in individual experience. It is a type of knowledge which is used by all people but which people do not necessarily find it easily to articulate. Tacit knowledge is thus difficult to codify or detach from individual researchers, employees or managers. It therefore does not submit of easy transfer by written or other verbalisation (Polanyi 1967). The 
transfer of tacit knowledge requires close and personal and ongoing interaction between 'instructor' and learner as well as strong efforts at assimilation.

Tacit knowledge is harder to copy and is therefore likely to lead to more lasting forms of competitive advantage than external, codified knowledge which is bought in. Regardless of the abilities of the learner, tacit knowledge requires significant time to acquire through experience and learning by doing. Once it is acquired, a skilled worker intuitively knows the adjustment to be made to a production process through a slight variance in materials, efforts or technique in a way that an inexperienced new starter would not know and would not be able to glean from an entirely rulesbased approach.

The above differences in the nature of these two types of knowledge are the reason why the difficulty in mastering new foreign innovation is low when a country has high capability in indigenous innovation. The possession of high capability in indigenous capability means that there exists strong in-house R\&D capacity, and it is important to recognize that R\&D activities is not just knowledge creation, it is also an educational experience because learning of potentially useful knowledge from every source supplies the raw ingredients for the process of knowledge creation to draw upon and to synthesize. Therefore, in-house R\&D is a crucial source for mastering external tacit knowledge because of the strong learning function of R\&D (Cohen and Levinthal 1989). Only with the successful internalization of the tacit knowledge of the foreign innovation can the foreign innovation be employed to reach its potential.

Another way to put it is that the ease with which a country can absorb new foreign technology depends positively on its in-house R\&D capacity. 6 Absorptive capacity is the ability of a country to identify, assimilate and exploit knowledge from the environment (Cohen and Levinthal 1989). In short, there is synergy between external sourcing of innovation and indigenous generation of innovation, and so a country should always draw on both, albeit with different degree at different developmental stages.

There are two other important reasons why the use of both sources of innovation is optimum. First, only in the presence of local innovation capacity will MNEs adopt a more integrated innovation practice, which has greater linkages with the local economy and thereby enables greater opportunities of knowledge transfer (Franco et al. 2011). Second, technical change is often biased in a particular direction and so the foreign technologies developed in industrialised countries may not be appropriate to the economic and social conditions of developing countries (Atkinson and Stiglitz 1969; Fu and Gong 2010). This requires the developing to have the indigenous capability to adapt this new technology to suit local conditions before the innovation could be adopted.

We have depicted schematically the Chinese open innovation approach of dual knowledge sources in Fig. 7. This open innovation program is a dynamic strategy, evolving with multiple driving forces to guide the direction of innovation and allocate resources advancement of the innovation capability of a country.

Before the reforms in the 1980s, the science and technology system in China was a closed innovation system that was inspired by the example of the Soviet Union (Xue 1997). Since the start of opening up and reform in the 1980s, China has been implementing an open national innovation approach. There has been investment in indigenous innovation over the years but with varying efforts at different stages of development: a small amount at the start that was mostly spent on absorption of foreign technology and development, followed by an emphasis on indigenous innovation starting in the late 1990s while maintaining high openness to external knowledge. 
The system has even become more active in knowledge sourcing after 2000, using unconventional channels that are not often used in developing countries, for example, outward direct investment, international innovation collaboration and attraction of highly skilled migrants. With the wider coverage of globalisation and the growth in the technological capabilities of Chinese firms, policy orientation has become even more open and aggressive in incentivising indigenous companies to acquire advanced external knowledge by 'going global'. At the same time, external sources such as foreign imported technologies and knowledge transferred back by returnees remain important complementarity mechanisms in boosting innovation.

There is little doubt that China's innovation performance has improved significantly, especially after 2000 , after the vigorous implementation of its proactive innovation policy. Figure 8reports the number of domestic patent applications to the Chinese State Intellectual Property Office (CPO) and the number of patents granted in the 1995-2012 period. The number of patent applications surged nearly 30-fold between 1995 and 2012, and the number of granted patents increased almost 25-fold during the same period.

The quantity of articles published in international journals by researchers based in Chinese universities has been increasing gradually since 2005. The number reached 320,345 in 2010, twice the number in 2005 (China Statistics Yearbook 2005, 2011).

Another indicator of the success of China's innovation strategy is the increasing importance of hightech trade. Figure 9 reports that, over the 1995-2012 period, the export of high technology products has increased from RMB 101 billion to RMB 6012 billion.

Even more notable in Fig. 9 is that China has become a net exporter of high-technology final products. The volume of high-tech exports was the same as the volume of high-tech imports in 1995-2005. In 2006, the same year that the 'Indigenous Innovation' strategy was launched, the export volume of high-tech products surpassed the import volume, with gap widening over time. By 2012, high-tech exports were $18.6 \%$ higher than high-tech imports. Registered the highest surplus in high-technology product trade. The total exports is USD 943 billion (18.6\%) higher than total imports in the high technology sector. The significant high-tech trade surplus is consistent with the proposition that China's innovation system is transitioning to an indigenous innovation-based system.

The three most important lessons from the interpretation of China's innovation policies by our Analytical Framework in Fig. 7 are that:

there is synergy between External Knowledge and Indigenous Innovation because the process of learning the tacit knowledge required in using the foreign technology fully is made easier by strong in-house $R \& D$ capability;

the open innovation approach is very important because it allows multiple driving forces-the state, the private sector and MNEs - with each playing a changing role over time; and

the commencement of foreign technology transfer and investment in indigenous innovation should go hand in hand. Without the numerous well-funded programs to build up the innovation infrastructure to increase the absorptive capacity of Chinese firms, the foreign technology would have remained static technology embedded in imported machines and would not have strengthened indigenous technological capability. 


\section{Final considerations: the next steps in China's innovation policy}

Throughout the last 30 years of high economic growth, China has consciously strived to move from being an imitative latecomer in technology to become a dynamic independent innovator in technology. China's road to indigenous innovation is characterised by a steady stream of new Science and Technology (S\&T) programs initiated by the state. The huge increase in technological capability has doubtless played an important part in transforming China from a low to a middleincome country. However, unless China keep moving up growth trajectories that are increasingly skill-intensive and technology-intensive, it risks being caught in the middle-income trap, where there would be not be a narrowing of the technological gap between China and the most technologicallyadvanced foreign countries.7

National innovation performance is a complex interaction of capabilities, incentives, and institutional factors. A country's capabilities (i.e. technological efforts, human capital and physical investment) define the best that can be achieved in innovation. The incentives at macro and micro levels will guide the use of these capabilities and stimulate their expansion, renewal and disappearance. Incentives determine the efficiency with which capabilities are used. More fundamentally, both of these factors operate within an institutional framework: for example, legal institutions (such as IPR protection and economic regulation), and educational institutions. These institutions set rules of the game and, through this, alter capabilities and change incentives.

There are two bottlenecks in China's capabilities. The first is creativity because the Chinese education system emphasizes respect for and attention to existing knowledge and doctrine, rather than fostering critical thinking and challenging existing limits. Root-and-branch reform of the current education system (reforming from the nursery level up) is a crucial step in the development of national innovation capabilities over the long run.

The second major bottleneck in capabilities to address is the inequality in access to innovation resources and the need for greater support of SMEs (which form the most dynamic sector in the economy), as well as the private sector in general (the most efficient innovator in the economy). According to the EC (2013), SMEs have been the major driver of innovation growth in EU countries. In China, state-owned firms are currently the major target of government R\&D programs. There is also the basic problem that SMEs face the world over (even in developed economies), they encounter very much greater difficulties in accessing financial resources. Therefore, even with a more liberalized financial sector in China, the government needs to set up targeted SME innovation funds and information support systems to promote the innovation activity of SMEs.

For incentives, the fundamental task for the government is to allow price signals from competitive markets to guide resource allocation. The task requires the government to continue facilitating the convergence of China's economic system to a modern market economy. The government must persist in reducing its intervention in the business and commercial sectors except in the cases of well-known market failures; for example, supporting basic research because it faces high risks and uncertainties and requires long-term investment to be sustained. The government should refrain from intervening in market-led activities such as the majority of the commercialization process, especially the scaling up of production activities. Otherwise, it will be impossible to prevent future cases where intervention by various local governments leads to a highly distorted investment pattern e.g. the lack of coordination among local governments and has led to overinvestment in the solar photovoltaics (PV) industry, creating a serious surplus in production capacity in this industry.

China has now almost completed the reform of the markets for final goods and services, with the transportation and telecommunication sectors being notable exceptions. The government should 
now accelerate the reform of the factor markets and of the markets for primary inputs. Interest rate deregulation, lowering of entry barriers for private financial institutions, reform of the property rights of rural land, termination of the household registration system, reform of the energy sector, and the reduction of indirect subsidies to state-controlled companies are the supply-side reforms are needed to generate the economic vitality needed for the growth of the New Normal Economy. The recent repeal of the One-Child Rule was a big step in the correct direction.

The state is the owner of almost all the universities and research institutes. To ensure that the incentives for innovation are powerful in these organizations, the state should adopt human resource management policies that:

- give higher weight to the quality than to the quantity of research outcomes in appraisals;

- use a researcher's/institution's performance in transforming their research outcomes into economic value and social impact as one of the appraisal criteria; and

- assess performance evaluation every 3-4 years instead every year, e.g. in UK universities, the Research Excellence Framework (REF) exercise is carried out every 5 years, and only the four highest quality research outputs are required to be submitted for the review by each academic staff member.

- At China's present status as a middle-income country, there are two institutions that China must establish in order to to entrench innovation in the economic system. The first is a strong intellectual property rights (IPR) institution that would:

- strengthen the transfer of outside knowledge to China. It is hard to disbelieve the frequent statements by foreign investors and MNEs that the relatively weak IPR protection in China has been discouraging them from using the most advanced technology in their production in China.8

- encourage indigenous innovation inside China.

The second most important institution to boost China's capability in innovation is the institution of external engagement in technology. This second institution is needed for China to respond appropriately to the globalization of the innovation system and to the increasingly contentious trade environment for China. This proposed institution of external engagement in technology will integrate China into the global innovation system by having the government:

- strengthen programs in international innovation collaboration and international knowledge co-production;

- encourage international technology acquisition through cross-border mergers and acquisitions by offering financial and diplomatic assistance; and

- actively attract highly skilled world-leading researchers for innovation projects in China; and

- actively participate in the global standard setting activities of international organizations.

In fine, we want to emphasize that even though this paper focuses only on how economic management could accelerate the pace of technological innovations in developing countries, we are not denying that the rate of technological progress is also powerfully influenced by innovations in the socio-political structure. Two examples come readily to mind about the mutually-reinforcing nature of technological innovations and institutional innovations in enabling a permanent rise in productivity.

The first example is the case of capital-biased technological innovations that would worsen the income distribution in favour of capitalists. This kind of innovation could shift the balance of political power such that social safety nets are weakened and human capital formation in the working class is 
reduced. One likely backlash would be social instability that disrupts production, followed by the adoption of populist policies that are inimical to long-run growth. Optimally (or if the country is lucky or governed well enough), there would be far-sighted leadership that would introduce institutional innovations to enhance social inclusion and social mobility such that the socially-destabilizing consequences of the capital-biased technological change are offset.

The second example of the complementary nature of technological innovations and socio-political institutional arrangements in undergirding robust productivity growth is based on Schumpeter's (1942) description of innovation as a "process of industrial mutation ... that incessantly revolutionizes the economic structure from within, incessantly destroying the old one, incessantly creating a new one." In short, accelerating the pace of innovation inevitably means a greater number of failed firms and displaced workers, creating a trade-off between the heightening of the level of social conflict in the short and medium-run and the reaping of bigger material benefits in the longrun.

Again, unless the short-run adjustment costs could be addressed adequately, the political backlash bring could reduce economic progress in the long-run. Well-designed socio-political institutional accommodation to compensate the losers is many times the requirement to allow the material benefits of technological innovations to be fully realized.

The above two examples make clear that (depending on the country, the time period, and the international context) the formulation of an effective economic plan for technological innovation might also require the simultaneous formulation of a plan for innovations in the broader sociopolitical sphere. In this paper, we have implicitly assumed that institutional innovations would occur as needed to enable satisfactory social acceptance of the technological innovation. 


\section{Footnotes}

1 Recent useful reviews of China's S\&T programs are Fu (2015), OECD (2008) and Varum and Huang (2007).

2 Source: Ministry of Science and Technology of the People's Republic of China: http://www.most.gov.cn/eng/.

3 Figures are calculated by the author from the data collected from the OECD Structural Analysis (STAN) database published by the OECD, and from the World Development Indicators published by the World Bank.

4 This external route is naturally limited by the country's ability to fund the investment.

5 Trott and Hartmann (2009) made the point that Chesbrough might be tilting at a straw man by presenting a rich trove of earlier literature that had advocated the use of both sources of innovation. For Chesbrough (2006), "while Open Innovation draws extensively from an earlier body of academic ownership, it offers a number of distinctive perspectives and interpretations of that prior scholarship. In our judgment, these are sufficient to warrant consideration as a new paradigm for understanding innovation." Chesbrough (2006) presented eight areas of differentiation.

6 The literature has also identified other factors that determine the absorptive capacity of a country. One important factor is the nature of the country's trade regime. Balassa $(1971,1982)$ documents that the growth performance of "outward-oriented" developing countries is superior to that of the "inward-oriented" developing countries. Other scholars have used different terms for this same dichotomy in trade regime, e.g. the World Bank (1985) calls the "outward-oriented" trade regime a "neutral-incentive" trade regime. Woo $(1990,2004)$ shows that the incentive effort in outwardoriented industrialization is to promote, in a non-selective manner, the production of tradable goods over the production of non-tradable goods. The empirical work of Rodrik (2008) supports the hypothesis that developing countries that biases production toward tradables have better growth outcomes.

7 For a broader discussion of other factors (beside failure in innovation) that could cause China to be caught in the middle-income trap, see Woo (2012).

8 In a study of 12 British enterprises operating in East Asia, Fu et al. (2006) found that these firms chose to use technology that was superior to local level rather than world class technology in their subsidiary or joint ventures in China. One key reason for this was their concern about the poor intellectual property rights protection in China. 


\section{REFERENCES}

Atkinson AB, Stiglitz JE (1969) A new view of technological change. Econ J 79(315):573-578

Balassa B (1971) The structure of protection in developing countries. Johns Hopkins Press, Baltimore

Balassa B (1982) Development strategies in semi-industrial economies. Johns Hopkins Press, Baltimore

Chesbrough, HW (2003) The Era of open innovation. MIT sloan management review, V44 N3, Spring 2003, April 15, 2003, pp 35-41

Chesbrough HW (2006) Open innovation: a new paradigm for understanding industrial innovation. In:

Chesbrough $\mathrm{H}$ et al (eds) Open innovation: researching a new paradigm. Oxford University Press, Oxford, pp 1-12

Cohen W, Levinthal D (1989) Innovation and learning: two faces of R\&D. Econ J 99:569-596

Cooper C (1989) Technology and innovation in international economy. United Nation University Press, The Netherlands

Diamond J (1997) Guns, germs, and steel: the fates of human societies. Norton, New York

Franco E, Ray S, Ray PK (2011) Patterns of innovation practices of multinational-affiliates in emerging economies: evidences from Brazil and India. World Dev 39(7):1249-1260

Fu X (2008) Foreign direct investment, absorptive capacity and regional innovation capabilities: evidence from China. Oxf Dev Stud 36(1):89-110

Fu X (2015) China's path to innovation. Cambridge University Press, Cambridge

Fu X, Gong Y (2010) Absorptive capacity and the benefits from global reservoirs or knowledge: evidence from a linked China-OECD dataset. SLPTMD Working Paper 31, University of Oxford Fu X, Cosh A, Hughes A, De Hoyos R, Eisingerich A (2006) The experiences of UK mid-corporate companies in emerging asian economies. UK Trade \& Investment, London. 2006 (URN 06/1137) Kamarck A (1976) The tropics and economic development: a provocative inquiry into the poverty of nations. Johns Hopkins University Press, Baltimore

Kuznets S (1966) Modern economic growth: rate, structure, and spread. Yale University Press, New Haven

Landes D (1998) The wealth and poverty of nations: why some are so rich and some are so poor. Norton, New York

Li XB (2011) Sources of external technology, absorptive capacity, and innovation capability in Chinese state-owned high-tech enterprises. World Dev 39(7):1240-1248

Marx K, Engels F (1848) The Communist manifesto. Republished by Washington Square Press (1964), New York 
North D, Thomas RP (1973) The rise of the western world: a new economic history. Cambridge University Press, Cambridge

OECD (2008) Reviews of innovation policy: China. OECD, Paris

Polanyi M (1967) The tacit dimension. Routledge \& Kegan Paul, London

Rodrik D (2008) The real exchange rate and economic growth. Brookings papers on economic activity, Fall

Schumpeter J (1942) Capitalism, socialism, and democracy. Harper \& Bros, New York

Solow RM (1970) Growth theory: an exposition. Oxford University Press, New York

Trott P, Hartmann DAP (2009) Why 'open innovation' is old wine in new bottles. Int J Innov Manag 13(4):715-736

Varum CA, Huang C (2007) China: building an innovative economy. Chandos, Cambridge

Wang H (2012) Globalizing China: the influence, strategies and successes of chinese returnees.

Emerald Publishing, Bradford

Weber, M (1905) The protestant ethic and the spirit of capitalism. Republished Routledge (1992), London

Woo, WT (1990) The art of economic development: markets, politics and externalities. Int Organ 44(3), Summer

Woo WT (2004) Serious inadequacies of the Washington consensus: misunderstanding the poor by the brightest. In: Teunissen JJ, Akkerman A (eds) Diversity in development: reconsidering the

Washington consensus. FONDAD (Forum on Debt and Development), The Hague, pp 9-43

Woo WT (2012) China meets the middle-income trap: the large potholes in the road to catching-up. J Chin Econ Bus Stud 10(4):313-336

World Bank (1985) World development report 1985: international capital and economic development. Oxford University Press, Oxford

Xue L (1997) A historical perspective of China's innovation system reform: a case study. J Eng Technol Manag 14:67-81

Zhou Y (2008) The inside story of China's high-tech industry: making "silicon valley" in Beijing. Rowman \& Littlefield Publishers, Lanham

Zhou Y, Hsu J-Y (2011) Divergent engagements: roles and strategies of Taiwanese and mainland Chinese returnees entrepreneurs in the IT industry. Glob Netw 11(3):398-411 